\title{
Forager-farmer connections in an 'unoccupied' land: First contact on the western edge of LBK territory
}

\author{
Bart Vanmontfort* \\ Faculty of Archaeology (Leiden University), c/o Prehistoric Archaeology Unit (K.U. Leuven), Geo-Institute, Celestijnenlaan 200E - pb 2409, B-3001 Leuven (Heverlee), Belgium
}

\section{A R T I C L E I N F O}

Article history:

Received 12 September 2006

Revision received 18 March 2008

\section{Keywords:}

Neolithisation process

Mesolithic

Hunter-gatherer

Neolithic

Linearbandkeramik

Site location choice

\begin{abstract}
A B S T R A C T
The interaction between local foragers and incoming farmers is one of the hot topics in the study of Europe's recent prehistory. In Central and Western Europe's loam region, occupied by the first farmers of the Linearbandkeramik (LBK), hunter-gatherer remains are scarce and consist mostly of surface finds. Hence, the hunter-gatherer occupation and activity on the loess has never been studied in detail. This paper tackles the problem of the visibility of hunter-gatherer activity on the loess belt. An interregional comparison of microlith datasets allows identifying behavioural changes and differences in exploitation intensity. With regard to forager-farmer interaction, a mutual influence in the spatial patterning of activity or settlement is demonstrated.
\end{abstract}

(c) 2008 Elsevier Inc. All rights reserved.

\section{The loess belt during the Early Holocene: unoccupied land?}

The interaction between local foragers and incoming farmers is one of the hot topics in the study of Europe's recent prehistory. It is closely related to the debate on the Neolithic spread over the continent. Traditional models of demic diffusion, in which agriculture was introduced in large parts of Europe by rapid movement of farmer communities, have been put in perspective by the acknowledgement of the complexity of the Mesolithic-Neolithic transition. Rather than a single process, this transition can be viewed as a mosaic of regionally varying and complex interactions between hunter-gatherers and immigrant farmers (e.g. Dennell, 1985; Price, 2000; Tringham, 2000; Zvelebil, 2004; Zvelebil and Lillie, 2000).

In the mid 6th Millennium cal BC, the loess region of Central and Western Europe was colonised by the first farmers of the Linearbandkeramik (LBK). The limits of LBK distribution correspond to one of the major agricultural frontier zones indicated by Zvelebil and Lillie (2000). The strict synchronism and contact between the last hunter-gatherers and first farmers within this frontier zone and thus the existence of a long availability phase (sensu Zvelebil, 1996; Zvelebil and Rowley-Conwy, 1986) is often assumed (Kind, 1997, pp. 129-133; Louwe Kooijmans, 2007; Van Gijn and Louwe Kooijmans, 2005; Verhart, 2000). It remains, however, difficult to demonstrate in the archaeological record. This is due to the scarcity of known sites from the Late or Final Mesolithic (Gronenborn, 1999; Jochim, 1990; Kind, 1997, pp. 19-20) and to

\footnotetext{
* Fax: +32 16322980.

E-mail address: bart.vanmontfort@ees.kuleuven.be
}

problems associated with the dating of those sites. The few available dates for Late Mesolithic sites beyond the 5300 cal BC LBK arrival date have been contested (see Crombé et al., 2005). Despite some indications of contact and exchange (Amkreutz et al., in press; Verhart, 2000, 2003; Zvelebil, 2000), it remains difficult to identify the nature of the forager-farmer relationship and even more difficult to associate changes in the behaviour of the last hunter-gatherers on the Pleistocene coversands with the arrival of the Neolithic.

In order to understand the Mesolithic-Neolithic transition a better knowledge of forager-farmer contacts is necessary. These contacts are likely to have affected the nature and rate of the transition (e.g. Zvelebil and Lillie, 2000). The loess belt, as the first region in Central and Western Europe to be occupied by Neolithic settlers, could have been the scene of such contacts. Evidence for hunter-gatherer activity on the loess is, however, scarce. A few sites are known in the floodplains of the rivers cutting through the loess belt (Kind, 2003; Mees et al., 1994; Parent et al., 1987; van der Sloot et al., 2003), but most remains consist only of Mesolithic points that were found isolated or within Neolithic flint scatters. This case holds true for most of the Northwest European loess region (e.g. Koch, 1998; Street et al., 2001, p. 428). No Atlantic hunter-gatherer camp sites have been excavated on the loess plateaus and the question arises as to what extent these plateaus were actually occupied.

The scarcity of data from the loess region has often been regarded as a confirmation of the loess plateaus' unappealing nature for late hunter-gatherers due to its dense Atlantic forest cover and presumed low general biodiversity (e.g. Garnett, 1945; Gronen- 
born, 1999, p. 137; Modderman, 1988; Verhart, 2003; see also Gregg, 1988). The general decrease in number of sites during the later Mesolithic phase would thus represent a shift in the settlement pattern (Gronenborn, 1999). Other scholars are convinced that hunter-gatherers did frequent the loess plateaus, but that their remains were destroyed or obscured by post-depositional processes: soil erosion affects plateau slopes and their edges, whereas the eroded sediment is deposited at the footslopes and in floodplains (e.g. Bogucki and Grygiel, 1993; Crombé and Cauwe, 2001; Gob, 1990; Kind, 2003; Modderman, 1988; Vermeersch, 1990; Zvelebil, 2000). Mesolithic camp remains can therefore be washed away or covered by sediment. Sites as Rebecq-Le Spinoi (Bosquet and Jadin, 1996) and Bedburg-Köningshoven (Street, 1995) are two clear, Early Mesolithic examples of such situations. The hunter-gatherer camp of Rebecq was covered by colluvium and did not leave a single trace at the present-day surface. The main settlement area of Bedburg was destroyed by lignite quarrying, which at the same time caused the discovery of its displaced remains in the calcareous gyttja top fill of a silted-up meander (Street, 1995). An absence of hunter-gatherer activity in the loess region can thus not be claimed a priori, but traces are more difficult to identify then elsewhere.

In this paper, a method is developed to map hunter-gatherer activity in regions like the loess region, where data on the Mesolithic occupation is meagre. Available data are, on a microregional scale, translated into chronological sequences. The interregional comparison of these sequences allows identifying changes in exploitation intensity on a regional scale. Mapping hunter-gatherer activity this way could also shed a light on forager-farmer interactions and the Mesolithic-Neolithic transition. Existent models of Neolithisation can be verified, for instance with regard to the question of whether the first forager-farmer contacts in this region were of a cooperative (Bogucki, 1988; Gregg, 1988; Zvelebil and Lillie, 2000) or an antagonistic (Keeley, 1992) nature. In this paper, the method is applied to the loess belt region of present-day Belgium and the Netherlands, i.e. the northwestern extension of Linearbandkeramik colonisation.

\section{Methods}

The low number of diagnostic artefacts and the frequent palimpsests severely hamper the chronological separation of occupation remains from different Mesolithic phases and thus the classification of Mesolithic surface scatters or isolated finds. It may even prove difficult to distinguish them from Neolithic material. Only Mesolithic points can be attributed to a particular phase with a reasonable degree of certainty, but due to the palimpsest problem they cannot be used to date an entire surface assemblage. Therefore, instead of working with full Mesolithic assemblages and camp remains, the analysis of the spatial and chronological distribution of individual microliths has been considered as an alternative method to gauge regional hunter-gatherer exploitation patterns and behavioural changes that may be related to an altering natural or socio-economic environment. An advantage of such an approach is that microliths found isolated as well as in larger surface scatters or excavations can be taken into account, which considerably enlarges the dataset. Moreover, it avoids problems associated with the homogeneity and/or site function of artefact scatters.

\section{Assumptions}

In the interpretation of microlith inventories several assumptions play a part. First, the available microlith datasets are taken as representative, random samples for the archaeologically knowable data in the regions under consideration. This representation depends on the correct identification of particular microliths. Problems can be encountered, for instance, with the distinction between late Mesolithic trapezes and Neolithic transverse arrowheads or between LBK arrowheads and 'developed' late Mesolithic points with inverse, flat basal retouch. An ongoing scrutiny of final Mesolithic and LBK points (Robinson, in preparation) should shed a light on the latter aspect. Awaiting the results of this study, the available microlith determinations are regarded as sufficient for the elaboration of the methodology. Another factor biasing the dataset is the possibility that microliths found in contexts other than surveys focusing on the prehistoric or Mesolithic occupation of the areas were not identified or reported as such and are thus not included in the existing datasets. Differences in research or survey activities are another, evident, biasing factor. However, rather than an obstacle to the correct interpretation of results, these factors are only complicating elements to be kept in mind. Very much like the aforementioned trapeze problem, they play the same role for all periods or phases in a given region. Ratios and differences in spatial distribution of the various microlith types should still yield significant results with regard to the identification of behavioural changes, either within the region under study or between different study areas.

The distribution of a particular artefact type offers different and complementary information as compared to data obtained by the excavation of sites (e.g. Ebert, 1992; Leopold and Vita-Finzi, 2005). A second assumption therefore pertains to what microliths represent. Generally there is no information available on the specific context of the microliths; it is rarely possible to determine whether they represent tools lost during their use or were remains of implement production or retooling within residential sites. Microliths represent, however, in all cases the exploitation of the region in which they were found.

Third, we assume that the microlith variation mainly reflects a chronological variability. This allows us to place the different types within fairly reliable relative and absolute chronological frameworks. Even though the presence/absence of particular microlith types has long been an important way to relatively date Mesolithic assemblages (Gob, 1981; Rozoy, 1978; Vermeersch, 1984), Lanting and van der Plicht (1997/1998, pp. 135-136) question the resolution of such framework (see also Crombé, 2002). The appearing and disappearing of microlith types is in their opinion impossible to date securely. Lacking well-stratified and reliably dated Mesolithic complexes, the existing typologies and seriations have indeed often been based on the association of microlith types and their abundance in surface assemblage compositions. For the study region of this paper, we refer to the examples of the Ourthe River Basin (Gob, 1981), the Belgian Campine area (Vermeersch, 1984) and Sandy Flanders (Crombé, 1998). ${ }^{1}$ Nowadays it has become clear that most of these sites are palimpsests (e.g. De Bie and Van Gils, in press; Lanting and van der Plicht, 1997/1998) and that neither the particular association of types nor related radiocarbon dates can be used to construct seriations. The Mesolithic of the Somme Valley (Ducrocq, 2001), on the other hand, situated to the southwest of this study region, can be regarded as a reliable reference. Based on stratified and reliably dated sites, the study of Ducrocq (2001) defines to what extent particular point types are specific to a certain time range. Even though the Somme Valley assemblages are not always uncontaminated, it appears possible to identify the most dominant periods in which particular types were in use. These data in no way allow identifying the age of any single point, but they reveal

\footnotetext{
${ }^{1}$ In his typology of the Campine Mesolithic, Vermeersch (1984) restricted the chronological implications of his distinguished groups to the 8000 BP boundary of trapeze presence/absence. The latter distinction is also what Lanting and van der Plicht (1997/1998, p. 136) regard as the only reliable distinction between an Early and Late Mesolithic.
} 
coarse patterns in the Mesolithic occupation of a particular region. The validity of Ducrocq's seriation for the middle Scheldt and middle Meuse Basins is supported by the fact that this seriation comprises data from a much larger region than only the Somme Basin and that all these regions were part of the Rhine-Meuse-Scheldt (RMS) 'Culture' territory as defined by Gob (1985; see also Heinen, 2006). Within that region, the introduction of particular microlith types will have differed slightly in time, but the major trends will be similar for the entire RMS Mesolithic (Gob, 1985; see also Heinen, 2006 and Ducrocq, 2001).

The fourth and final assumption is that of interregional comparability. Factors such as chronological variation in technique and typo-morphology of microliths are assumed to have been uniform within certain geographical limits, such as the middle Scheldt and middle Meuse Basins. At this scale they should not have significantly biased patterns in exploitation behaviour. The comparison of these factors between samples from different regions should allow the identification of behaviourally significant trends.

\section{Data}

The microlith data from the middle Scheldt loess region were gathered in the framework of a Master's dissertation a quarter of a century ago (van de Konijnenburg, 1980) and were supplemented with more recent data, assembled by Van Assche (2005). Despite several clusters of intensive survey activity, e.g. in the southwestern part of the province of Brabant Wallon, southwest of Brussels (Fourny and Van Assche, 1987, 1993), only limited additional data were collected and no recent inventories have been made. The archaeological site databases of Flanders (Central Archaeological Inventory) and the Walloon region do not yield additional or easily accessible data either. Our dataset can be regarded as fairly complete and a representative sample (e.g. also Van Assche, 2005) and reveals a low find density of Mesolithic sites or artefacts in the loam region.

Most of the microliths of which the original context is known, were found isolated or in mixed assemblages dominated by Neolithic artefacts. Indications of larger residential hunter-gatherer camps-using Binford's terminology (Binford, 1982)-are absent. The sites may consequently have been part of a settlement system that encompassed exploitation territories extending beyond the loess zone. The possibility of such large exploitation territories was also shown for the Mesolithic of Northern England by Donahue and Lovis (2006), who claim it fits with the large territories exploited by the northern boreal forest hunter-gatherers of North America (see e.g. Kelly, 1995; Lovis et al., 2005).

Van de Konijnenburg sampled microliths from a $2650 \mathrm{~km}^{2}$ area that covers large parts of the present-day provinces of Hainault and Brabant Wallon (Fig. 1). The Hainault LBK settlement cluster is located in the western part of this region. Two sub-regions have been selected for the aims of this paper, based on a combination of find density, pedology and distance from the nearest LBK village. The first region comprises sites and finds located within a $25 \mathrm{~km}$ range around the Hainault LBK settlement cluster. The soils of this region are mainly loamy soils on a substratum with varying permeability. The sites and finds in this region delimit an area of approximately $1000 \mathrm{~km}^{2}$ with a find density of 1.5 microlith per $10 \mathrm{~km}^{2}$. A second region is located in Southwest Brabant, in between the $25 \mathrm{~km}$ radii around the LBK settlements in Hainault to the west and those in Hesbaye and Kleine Gete to the east. It covers approximately $900 \mathrm{~km}^{2}$, with a hilly topography and soils developed on loam and locally Tertiary sand. The find density of 3.3 microliths per $10 \mathrm{~km}^{2}$ is higher than in Hainault.

Readily available data from several neighbouring regions were collected for purposes of interregional comparison. These neighbouring regions include the Hageland, Ourthe Basin and four re- gions in the Meuse Valley, i.e. from south to north Graetheide, Roerstreek, Venray and Grave. The Hageland region is situated north of the loess belt region (Fig. 1). Its relief is dominated by sandstone hills, i.e. the remains of Miocene sandbanks (Goossens, 1983, pp. 120-121) covered with sandloamy sediments. From early on, Hageland is characterized by a fairly high archaeological research intensity. The stone age finds were subjected to an exhaustive analysis during the late 1960s and early 1970s (Vermeersch, 1976) that revealed the importance of the local Mesolithic occupation. Within the Hageland region Vermeersch noted a shift in location choice around the Middle Mesolithic. In the later phases, wetter loamy soils on levees and in valley locations were progressively abandoned in favour of the drier sandy hilltops of the region (Vermeersch, 1976).

The analysis of the Ourthe Basin Mesolithic also dates from the 1970s (Gob, 1981; Henrard, 2003). This region is situated to the southeast of Liège (Fig. 1). Its dissected relief is covered by loam soils with stony admixture of psamite, schist and limestone. Based on an identification of site types, Henrard (2003) noted a shift from an intense residential occupation towards a merely logistic exploitation of the Ourthe Basin around $7800 \mathrm{cal} \mathrm{BC}$. This implies, according to Henrard (2003), the residential relocation of the population towards neighbouring regions and to the loess belt in particular. It fits perfectly with the disappearance of funerary sites in this region (Vanmontfort, 2007).

A third region of comparison is the Dutch Meuse Valley. Data on the dense Mesolithic occupation of this region were gathered by Wansleeben and Verhart (1998) in the framework of the 'Meuse Valley Project'. One out of four research scales of this project included the scrutiny of all museum and private collections from four 'core regions' of approximately $100 \mathrm{~km}^{2}$ (Roerstreek, Venray, Grave and Graetheide; Fig. 1). This approach yielded a dataset free of inaccuracies that are caused by the non-identification of microliths or by the lack of publications. The physiography of these regions varies from loess plateaus (Graetheide) and slightly rolling coversand areas (Venray) to old river clay soils (Grave). Most Mesolithic data in this region were derived from small flint surface scatters, suggesting small groups of hunter-fisher-gatherers migrating in a yearly cycle (Verhart, 2000, p. 48).

In order to arrive at comparable datasets, the inventories characterised by often differing microlith nomenclature were translated to a classification in six types: points with unretouched base, points with retouched base, points with invasive or surface retouch, ${ }^{2}$ crescents, triangles and trapezes (Fig. 2).

\section{Phasing of microliths}

In the Somme Valley Mesolithic, Ducrocq (2001) distinguishes four Mesolithic phases, dated between 9800-9200/9100 BP, 9200/9100-8500 BP, 8500-7800 BP and 7800-6100 BP (Ducrocq, 2001, $211 \mathrm{ff}$ ) and in this paper labelled as Pre-boreal, Early Boreal, Late Boreal and Atlantic Mesolithic. The first phase of the regionally more commonly used Early/Middle/Late Mesolithic division (Crombé and Cauwe, 2001), more or less corresponds with the first two phases of Ducrocq.

Data provided by Ducrocq demonstrate that most microlith types are not exclusively connected to one of the distinguished phases. To arrive at a reliable estimation of the total number of microliths per phase, the microlith counts have to be transformed statistically. This is done using a fixed ratio that was based on the importance of the various microlith types in each of the phases and

\footnotetext{
2 "Points with invasive retouch" is a particular group of microlith types of which the dorsal and/or ventral surface is partially or fully covered by flat retouch. This group includes 'feuille de gui' points as well as 'points with rounded base' and 'invasively retouched triangles'.
} 


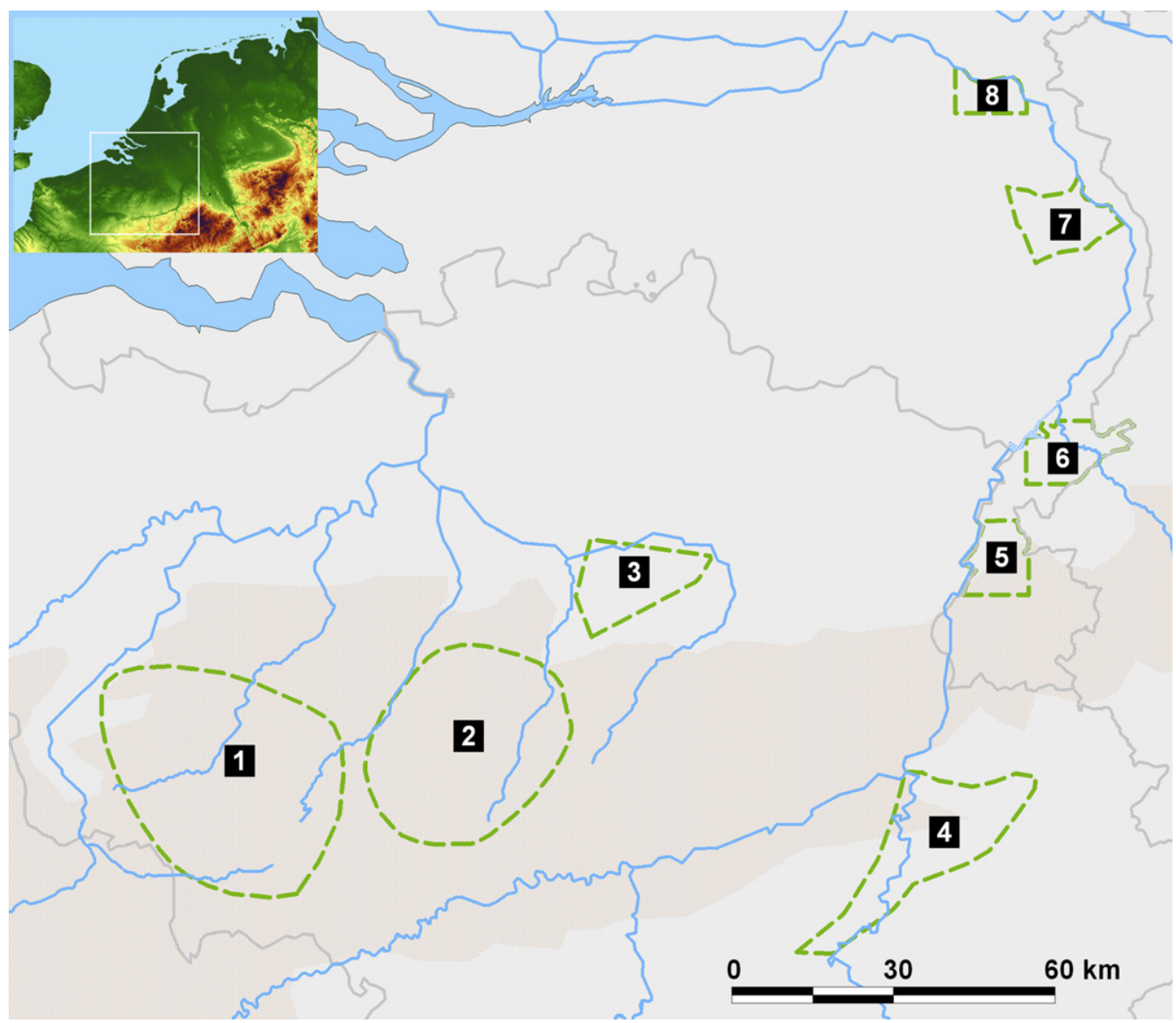

Fig. 1. Delimitation of sampled regions: 1. Hainaut, 2. SW Brabant, 3. Hageland, 4. Ourthe Basin, 5. Graetheide, 6. Roerstreek, 7. Venray, 8. Grave.

the estimated time ranges of these phases. The Somme Valley data confirm the commonly accepted North Belgium/Southern Netherlands relative chronological sequence of crescents older than triangles older than invasive retouch older than trapezes, with overlaps in particular in the earlier Mesolithic stages. Points with retouched and unretouched base occur during a wider time range, but unretouched bases are mainly associated with the early phases and retouched bases with the later Mesolithic. In the absence of precise data, an estimation $(E)$ is used to represent the use of each microlith type in each phase (Table 1 ). $E_{i j}$ for microlith type $i$ in Mesolithic phase $j$ is expressed on a $0-1$ scale, ranging from the absence $(0)$ to the exclusive presence (1) of that microlith type in that particular phase (Table 1 ). The sum of all $E_{i}$ of microlith type $i$ is 1 .

Longer periods are more likely to yield particular microliths than shorter periods. Hence, the duration of each phase should be taken into account as well. For a microlith with a homogeneous use in all four phases, i.e. all $E_{j}$ equal 0.25 , this means that the probability for a particular microlith to date from a period with duration $\Delta t$ equals:

$P_{i j}=\frac{\Delta t_{j}}{\sum_{j=1}^{n} \Delta t_{j}}$

If not all periods have an equal estimated importance $E$ for a particular microlith, the situation is slightly different. In this case, the probability Eq. (1) should be multiplied by the individual estimations $E_{\mathrm{ij}}$. This brings us to the following formula for the calculation of allocation factor $A_{\mathrm{ij}}$, refining estimation $E_{\mathrm{ij}}$ :

$A_{i j}=E_{i j} \cdot \frac{\Delta t_{j}}{\sum_{j=1}^{n}\left(E_{i j} \cdot \Delta t_{j}\right)}$ where $\Delta t_{j}$ is the estimated duration of Mesolithic phase $j$. The best possible estimate of the total number of microliths representing a particular phase is the sum of all individual microlith type counts multiplied by their specific allocation factor $A_{\mathrm{ij}}$ for that phase, or:

$N_{j}^{\prime}=\sum_{i=1}^{n}\left(N_{i} \cdot A_{i j}\right)$

There are some aspects that require clarification. First, differences in hafting or combining microliths in the subsequent phases, may result in rather different numbers of microliths produced, used and-finally-found. In the case of arrow equipment, this predominantly affects trapezes and invasively retouched points compared to other microliths. Trapezes may be regarded as a contraction of point and barb (e.g. Thévenin, 1992) or as points without barbs. As the Atlantic Mesolithic is almost exclusively represented by this type (Table 1), the number of trapezes is probably an underestimation of actual activity in that period as compared to the other phases; the factor of this underestimation is, however, unknown. This problem is less prominent for the points with invasive retouch, since the Late Boreal period is characterized by a more varied set of microlith types.

Second, there are considerable interregional differences in the microlith ratios (Table 2). Most differences relate to the Late Boreal and Atlantic periods. These differences may originate from the use of a fixed allocation factor $A_{\mathrm{ij}}$. As a result of this method, and of the fact that several microlith types can be attributed to different chronological phases, incorrect assignments are possible and may blur fluctuations in activity intensities. This is shown by the fairly well known Ourthe Basin assemblage. Earlier studies demonstrated the contrast between the intense habitation and exploitation of this region during the Pre-boreal and Early Boreal periods and the low 


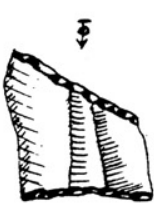

13
14
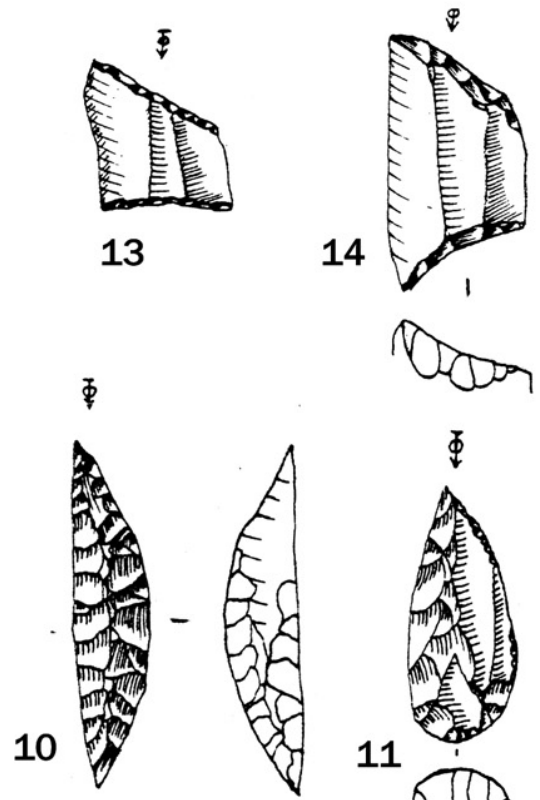

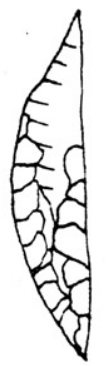

11

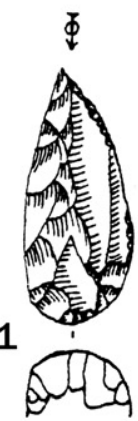

15

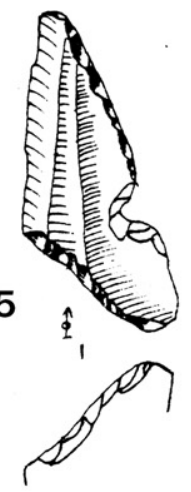

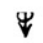

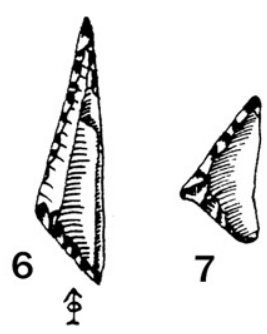

8

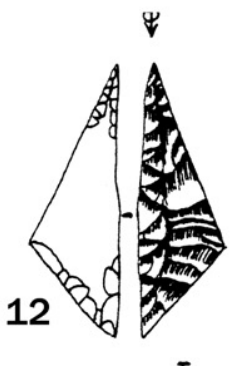

$\Phi$
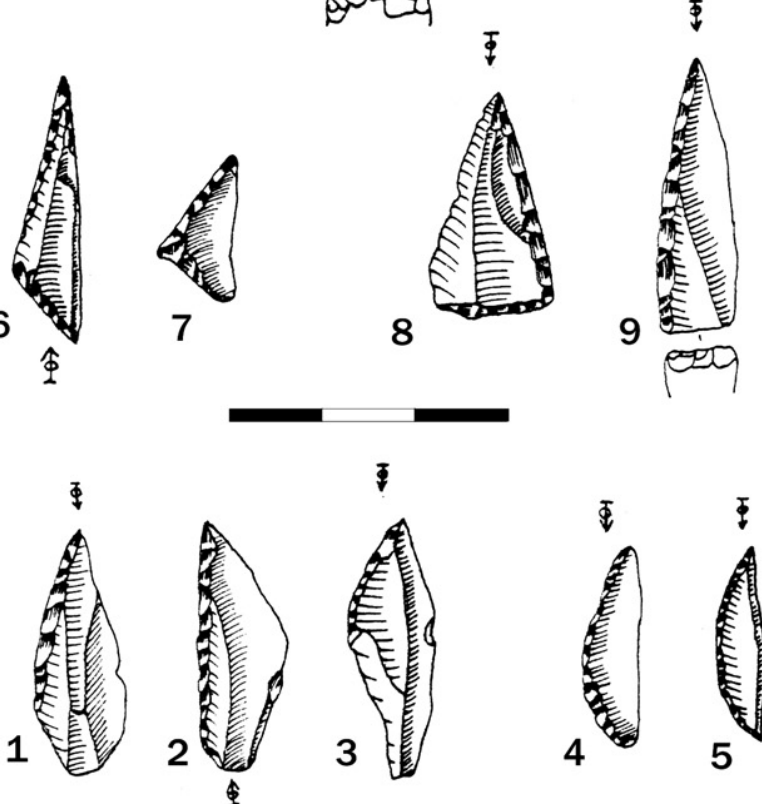

Fig. 2. Distinguished microlith types. 1-3: points with unretouched base, 4-5: crescents, 6-7: triangles, 8-9: points with retouched base, 10-12: points with invasive retouch, 13-15: trapezes. All drawings taken from van de Konijnenburg (1980).

activity intensity during Late Boreal and Atlantic times (Gob, 1981; Henrard, 2003). Due to the amplitude of the difference, even a small percentage of older type microliths attributed to the later periods automatically corresponds to a relatively large number compared to the later type microliths, i.e. invasively retouched points in the Late Boreal and trapezes in the Atlantic period. This explains the smaller proportion of these microlith types in the total microlith numbers in Late Boreal and Atlantic phases (Table 2).

In order to compensate for this effect in the later Mesolithic phases, one can assume an average proportion of points with invasive retouch and trapezes and adjust the $N_{\mathrm{j}}^{\prime}$ values accordingly. The average proportion is calculated by averaging the percentages provided in Table 2. It was chosen to base the average on all available data in spite of the clear outlier status of Ourthe Basin and the very small number of microliths from Graetheide. The resulting values are $55 \%$ points with invasive retouch in the Late Boreal and $89 \%$ trapezes in the Atlantic Mesolithic. The total number of microliths in those phases $\left(N_{\mathrm{j}}\right)$ can then be adjusted according to these averages by dividing the total number of points with invasive retouch and trapezes by the average percentages. For each of the regions, points with invasive retouch and trapezes thus correspond to $55 \%$ and $89 \%$ for their respective phases. If the difference $\left(D_{\mathrm{j}}\right)$ between $N_{\mathrm{j}}^{\prime}$ and $N_{\mathrm{j}}$ is positive, it corresponds to 'older type' microliths erroneously attributed to these phases and to be redistributed over the older Mesolithic phases. Negative differences, conversely, correspond to 'older type' microliths wrongly attributed to the older phases and to be recovered from those phases. For the Atlantic period, all positive and negative differences are points with unretouched base of which $96 \%$ has to be allocated to or collected from the Pre-boreal period and 4\% from the Early Boreal. ${ }^{3}$ In the Late Boreal, on the other hand, three microlith types are affected: points with unretouched base, triangles and points with retouched base. The contribution of each of those microlith types to $D_{\text {Late Boreal }}$ is proportionally the same as their contribution in the calculated number of microliths in this phase $N_{\text {Late Boreal }}^{\prime}$. For triangles, for example, this proportion is represented by the following formula:

proportion $_{t, \mathrm{LB}}=\frac{N_{t, \mathrm{LB}}}{\left(N_{r}+N_{t}+N_{u}\right)_{\mathrm{LB}}}$

where $r$ is points with retouched base, $t$ is triangles, $u$ is points with unretouched base and LB is Late Boreal. Consequently, the contribution of the microlith types to $D_{\mathrm{LB}}$ can be calculated by multiplying the proportions from (4) by the difference $D_{\mathrm{LB}}$ :

$\begin{aligned} R_{\mathrm{LB}} & =\frac{r_{\mathrm{LB}}}{r_{\mathrm{LB}}+t_{\mathrm{LB}}+u_{\mathrm{LB}}} \cdot D_{\mathrm{LB}} \\ T_{\mathrm{LB}} & =\frac{t_{\mathrm{LB}}}{r_{\mathrm{LB}}+t_{\mathrm{LB}}+u_{\mathrm{LB}}} \cdot D_{\mathrm{LB}} \\ U_{\mathrm{LB}} & =\frac{u_{\mathrm{LB}}}{r_{\mathrm{LB}}+t_{\mathrm{LB}}+u_{\mathrm{LB}}} \cdot D_{\mathrm{LB}}\end{aligned}$

where capitals $R, T$ and $U$ correspond to the contribution of points with retouched base, triangles and points with unretouched base, respectively, to the difference $D_{\mathrm{j}}$; lower case $r, t, u$ correspond to the contribution of those types to $N_{\mathrm{j}} . R_{\mathrm{LB}}, T_{\mathrm{LB}}$ and $U_{\mathrm{LB}}$ are allocated to or collected from the Pre-boreal and Early Boreal period based on an adjusted allocation factor $A_{\mathrm{ij}}$, this time taking into consideration that $100 \%$ should be distributed over these two phases only. For points with retouched base, triangles and points with unretouched base, the adjusted allocation factors are $0.17 / 0.83,0.42$ / 0.58 and $0.96 / 0.04$, respectively. The resulting values $N_{\mathrm{j}}$ are presented in Table 3.

In a quantitative diachronic comparison of patterns and frequencies, the unequal length of each phase has to be compensated. This is done by dividing the total number of microliths allocated to phase $j$ by the duration of that phase. The result is an estimation of the microlith density per millennium or $N / \operatorname{kyr}$ (Table 3 ).

\section{Identifying trends}

An interregional comparison of trends in hunter-gatherer exploitation activity

The result of the calculation is displayed in a table showing the estimated and phased number of microliths per millennium found in each of the study regions. Diachronic changes in the microlith frequencies in a particular region are a proxy for the evolution in hunter-gatherer exploitation intensity. Interregional trend differences are most informative on differences in exploitation intensity.

\footnotetext{
${ }^{3} 96 \%$ and $4 \%$ are adjustments of the $A_{\mathrm{ij}}$ values, based on the allocation of $100 \%$ of
} the microliths to the Pre-boreal and Early Boreal periods. 
Table 1

Allocation factors of microlith types over time

\begin{tabular}{|c|c|c|c|c|}
\hline & $\begin{array}{l}\text { Pre-boreal } \\
9300-8300 \text { cal BC }\end{array}$ & $\begin{array}{l}\text { Early Boreal } \\
8300-7600 \text { cal BC }\end{array}$ & $\begin{array}{l}\text { Late Boreal } \\
7600-6600 \text { cal BC }\end{array}$ & $\begin{array}{l}\text { Atlantic } \\
6600-5000 \text { cal BC }\end{array}$ \\
\hline \multicolumn{5}{|l|}{$\overline{E_{\mathrm{ij}}}$} \\
\hline Unretouched base & 0.85 & 0.05 & 0.05 & 0.05 \\
\hline Crescent & 0.50 & 0.50 & 0 & 0 \\
\hline Triangle & 0.30 & 0.60 & 0.10 & 0 \\
\hline Retouched base & 0.10 & 0.70 & 0.20 & 0 \\
\hline Invasive retouch & 0 & 0 & 1 & 0 \\
\hline Trapeze & 0 & 0 & 0 & 1 \\
\hline \multicolumn{5}{|l|}{$A_{\mathrm{ij}}$} \\
\hline Unretouched base & 0.84 & 0.03 & 0.05 & 0.08 \\
\hline Crescent & 0.59 & 0.41 & 0 & 0 \\
\hline Triangle & 0.37 & 0.51 & 0.12 & 0 \\
\hline Retouched base & 0.13 & 0.62 & 0.25 & 0 \\
\hline Invasive retouch & 0 & 0 & 1 & 0 \\
\hline Trapeze & 0 & 0 & 0 & 1 \\
\hline
\end{tabular}

For an explanation of $E_{\mathrm{ij}}$ and $A_{\mathrm{ij}}$, see text.

Table 2

Proportion of each of the microlith types in each of the distinguished phases and regions, after application of allocation factor $A_{\mathrm{ij}}$ (formula (2))

\begin{tabular}{|c|c|c|c|c|c|c|c|c|c|}
\hline & Hainaut (\%) & SW Brabant (\%) & Hageland (\%) & Ourthe Basin (\%) & Graetheide (\%) & Roerstreek (\%) & Venray (\%) & Grave (\%) & Average \\
\hline \multicolumn{10}{|l|}{ Pre-boreal } \\
\hline Unretouched base & 63 & 65 & 53 & 54 & 0 & 91 & 82 & 74 & $60 \% \pm 28$ \\
\hline Crescent & 6 & 6 & 15 & 16 & 0 & 2 & 2 & 2 & $6 \% \pm 6$ \\
\hline Triangle & 23 & 21 & 21 & 23 & 0 & 5 & 10 & 20 & $15 \% \pm 9$ \\
\hline Retouched base & 9 & 8 & 11 & 6 & 100 & 3 & 6 & 5 & $18 \% \pm 33$ \\
\hline \multicolumn{10}{|l|}{ Early Boreal } \\
\hline Unretouched base & 3 & 4 & 2 & 3 & 0 & 14 & 7 & 6 & $5 \% \pm 4$ \\
\hline Crescent & 5 & 6 & 11 & 15 & 0 & 4 & 2 & 3 & $6 \% \pm 5$ \\
\hline Triangle & 39 & 39 & 32 & 42 & 0 & 26 & 31 & 51 & $33 \% \pm 15$ \\
\hline Retouched base & 53 & 51 & 55 & 40 & 100 & 55 & 60 & 41 & $57 \% \pm 19$ \\
\hline \multicolumn{10}{|l|}{ Late Boreal } \\
\hline Unretouched base & 2 & 9 & 4 & 11 & 0 & 24 & 10 & 10 & $9 \% \pm 7$ \\
\hline Triangle & 4 & 16 & 8 & 26 & 0 & 7 & 7 & 16 & $11 \% \pm 8$ \\
\hline Retouched base & 8 & 36 & 24 & 44 & 20 & 26 & 24 & 22 & $25 \% \pm 11$ \\
\hline Invasive retouch & 87 & 39 & 64 & 19 & 80 & 43 & 58 & 52 & $55 \% \pm 22$ \\
\hline \multicolumn{10}{|l|}{ Atlantic } \\
\hline Unretouched base & 6 & 9 & 5 & 35 & 0 & 20 & 7 & 8 & $11 \% \pm 11$ \\
\hline Trapeze & 94 & 91 & 95 & 65 & 100 & 80 & 93 & 92 & $89 \% \pm 11$ \\
\hline
\end{tabular}

Table 3

Total number of microliths in each of the distinguished regions $\left(\mathrm{N}_{\mathrm{j}}\right)$

\begin{tabular}{|c|c|c|c|c|c|c|c|c|c|c|}
\hline & \multicolumn{2}{|c|}{ Pre-boreal } & \multicolumn{2}{|c|}{ Early Boreal } & \multicolumn{2}{|c|}{ Late Boreal } & \multicolumn{2}{|c|}{ Atlantic } & \multicolumn{2}{|l|}{ Total } \\
\hline & $N$ & $N /$ kyr & $N$ & $\mathrm{~N} / \mathrm{kyr}$ & $N$ & $\mathrm{~N} / \mathrm{kyr}$ & $N$ & $N /$ kyr & $N$ & $\mathrm{~N} / \mathrm{kyr}$ \\
\hline Hainaut & 22 & 22 & 6 & 9 & 98 & 98 & 31 & 20 & 157 & 35 \\
\hline SW Brabant & 109 & 109 & 87 & 124 & 28 & 28 & 69 & 43 & 293 & 65 \\
\hline Hageland & 64 & 64 & 60 & 86 & 63 & 63 & 76 & 47 & 263 & 58 \\
\hline Ourthe Basin & 769 & 769 & 621 & 887 & 63 & 63 & 73 & 45 & 1525 & 339 \\
\hline Graetheide & 0 & 0 & 0 & 0 & 2 & 2 & 8 & 5 & 1 & 2 \\
\hline Roerstreek & 254 & 254 & 68 & 97 & 38 & 38 & 89 & 55 & 449 & 100 \\
\hline Venray & 77 & 77 & 37 & 53 & 35 & 35 & 90 & 56 & 239 & 53 \\
\hline Grave & 112 & 112 & 63 & 90 & 40 & 40 & 99 & 62 & 313 & 70 \\
\hline
\end{tabular}

The data for the two sub-zones in the Scheldt Basin loess region show different trends (Fig. 3). In Hainault there is a distinct maximum in the Late Boreal and a sharp drop in the Atlantic period. In SW Brabant, on the other hand, a marked drop occurs as early as the Early/Late Boreal transition and is followed by a slight increase in the Late Boreal/Atlantic transition. No external factors can explain the differences between these two regions. They are spatially connected and characterized by a similar physiography. The sample sizes are sufficiently large and not biased by larger assemblages. This is adequately shown by the different distributions in Fig. 4 , in which the weight attributed to each site is varied. The ma- jor trends and interregional differences are more or less maintained in each of the frequency graphs. The regions apparently had different occupation or exploitation histories.

Nearly all other regions roughly follow the general decreasing trend of the SW Brabant sample. The Hageland sample (Fig. 3), for instance, also has an Early Boreal maximum of microliths. The slight drop at the Late Boreal/Atlantic Mesolithic, on the other hand, is in contrast to SW Brabant. This 25\% drop is much smaller than that in Hainault (80\%) and similar to that of the Ourthe Basin (28\%, see below). In Hageland, it is uncertain whether the Atlantic drop corresponds to a decrease in exploitation activity, given the 
a

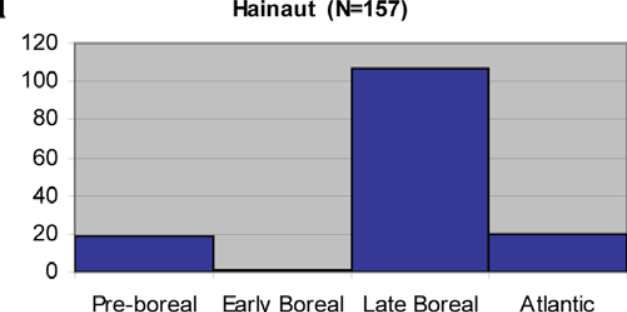

Hage land $(\mathrm{N}=263)$

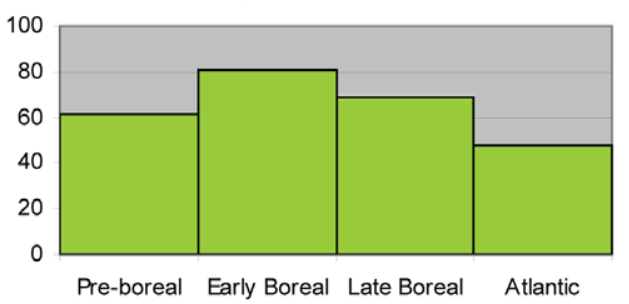

Graetheide $(\mathrm{N}=10)$
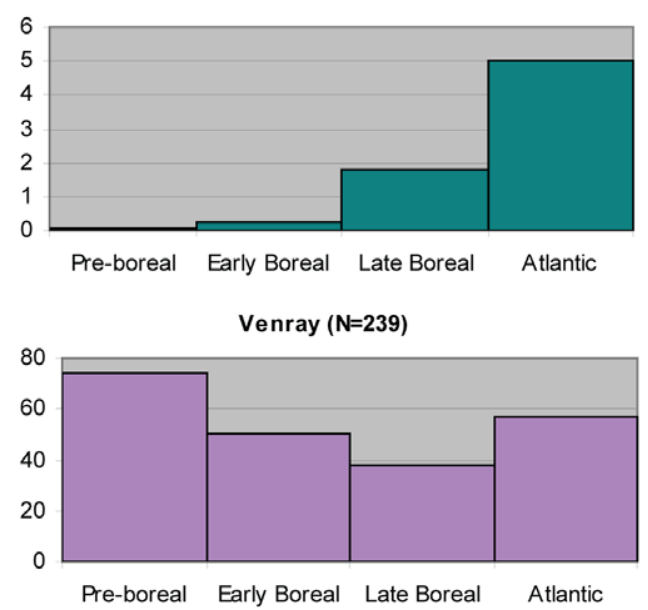

SW Brabant ( $\mathrm{N}=293$ )

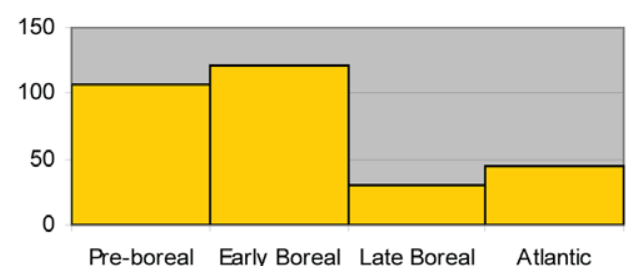

Ourthe Basin ( $\mathrm{N}=1525)$

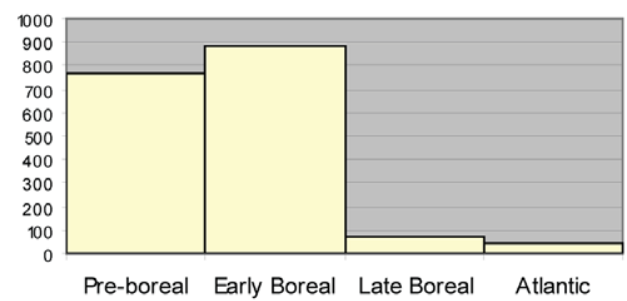

Roerstreek ( $\mathrm{N}=449)$

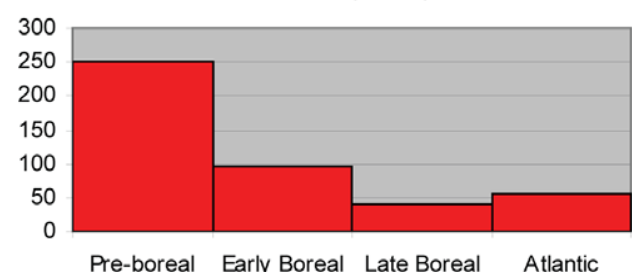

Grave $(\mathrm{N}=313)$

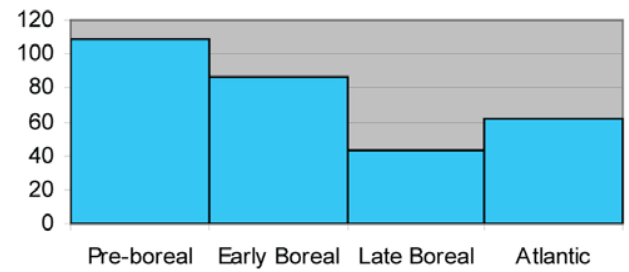

b

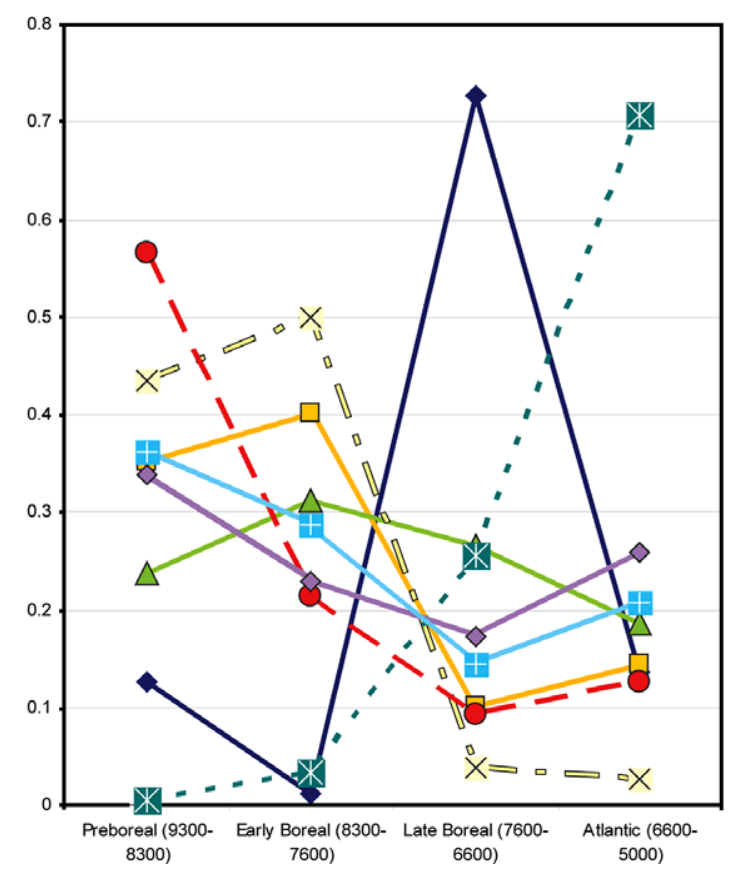

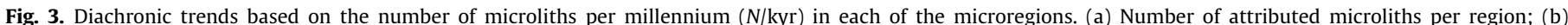
percentages. 

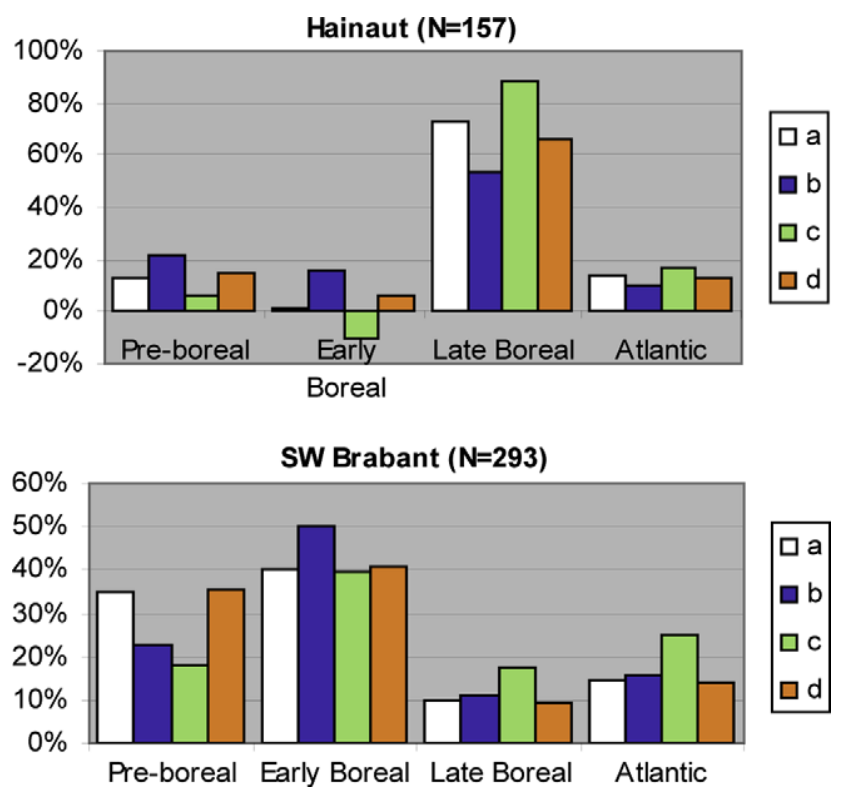

Fig. 4. Trends in the Hainaut and SW Brabant regions (\% of number of microliths over time). (a) $N / \mathrm{kyr}$ per phase; (b) $N$ proportionately recalculated per site based on an equalisation of the total number of microliths per site; (c) $N$, at sites with in total more than 5 microliths proportionately reduced to 5 ; (d) presence/absence of microliths, at each site the frequency of present microlith types is reduced to 1 .

arguments for a differential representation of trapezes and nontrapezes mentioned above. The spatial distribution of individual microliths supports the pattern identified by Vermeersch (1976 and see above): Whereas older microlith types mainly occur in valley locations, points with invasive retouch and trapezes are more often found on hilltop locations (Table 4).

In the Ourthe Basin, the Early/Late Boreal drop is more prominent than elsewhere (Fig. 3). This data corresponds to the pattern identified by Henrard (2003, see above). It shows a marked change in the exploitation intensity of the region. At the same time, this correspondence corroborates the idea that behavioural changes on a regional scale can be traced on the basis of individual microlith counts.

The trend of microlith frequencies is remarkably homogeneous in the three Meuse Valley regions that are situated north of the loess zone: Roerstreek, Venray and Grave (Fig. 3). Pre-boreal microliths dominate. After a drop towards the Late Boreal, the number of microliths rise again in the Atlantic.

The Graetheide 'core region', located in the loess zone, is entirely different. It is characterised by an overall scarcity of microliths, apart from two exceptions all to be dated in the Atlantic Mesolithic (Fig. 3). This scarcity is a primary pattern as the collections of this region were catalogued in exactly the same way as the

\section{Table 4}

Physiographic context of the microliths in Hageland

\begin{tabular}{lccc}
\hline & \multicolumn{2}{l}{ Location } & \\
\cline { 2 - 4 } & Hilltop & River floodplain & Total \\
\hline Find locations & 63 & 15 & 78 \\
Unretouched base & 14 & 28 & 42 \\
Crescent & 1 & 16 & 17 \\
Triangle & 12 & 26 & 38 \\
Retouched base & 16 & 36 & 52 \\
Invasive retouch & 19 & 15 & 34 \\
Trapeze & 40 & 23 & 63 \\
Total & 102 & 144 & 246
\end{tabular}

Of 17 microliths no exact find location is known. other regions (L. Verhart, pers. comm.) and as the total number of find locations is similar to Venray and Grave. Apparently the entire Graetheide region was practically void of hunter-gatherer activity.

\section{Discussion}

\section{Trend difference authenticity}

Several interacting uncertainties bias the calculated patterns: the allocation factor $A_{\mathrm{ij}}$ is based on estimated figures, the chronological resolution is coarse with phases of 1-1.5 millennia, sample sizes and research activity differ between the reference regions and the particular taphonomy obscures a direct link between microlith distributions and the activity of which they are the remains. A finegrained resolution can therefore not be obtained. Larger trends, however, are immune to many of these biasing factors and other factors are the same for each of the regions and therefore not biasing interregional differences. This is substantiated by the following arguments.

First, major diachronic changes are preserved if allocation factor $A_{\mathrm{ij}}$ is modified. Interregional differences are even independent of these variations: tempering a drop or rise in number of microliths in one region enforces contrasting changes in others. The observed contrasting patterns are therefore authentic.

Second, the coarse resolution obscures the possible complexity in exploitation changes, but is more likely to have blurred actual trends than to have created false ones. This is especially the case if major changes do not coincide in time with the common Mesolithic phase boundaries.

Third, and relating to possible differences in sample size and research activity, each of the samples should be regarded as a random one. The reliability of the proportional composition of these samples is demonstrated by that of Hainault. In a recent study, Van Assche (2005) added to the catalogue 15 locations with in total 63 microliths or $40 \%$ of the entire Hainault sample. Excluding these data, however, does not significantly affect the observed patterns. Major interregional differences are thus the result of different changes in exploitation intensity during the Early Holocene.

These arguments confirm that the impact of the biasing factors on the major regional trends and interregional differences was limited. The value and authenticity of these trends and differences can thus be claimed.

\section{Interpreting observed differences}

Diachronic changes in the number of microliths can represent a change in hunting or hafting techniques, a change in exploitation systems, a population change either with or without migration, or a combination of these. Interregional trend differences should then be related to these changes and their impact in the respective regions. Each of the shifts may have been triggered by environmental or social change. It should be kept in mind that the graphs (Fig. 3) merely represent trends and patterns in microlith numbers and are in se no population curves. The calibration of the graphs into population curves depends on unknown factors such as diachronic differences in microlith use and hunting strategies.

A first major change occurred in several regions around the middle of the Boreal period. The number of microliths decreases in SW Brabant and the Ourthe Basin, while in Hainault a prominent rise is visible. As was already proposed by Henrard (2003) for the Ourthe Basin, this pattern represents an exploitation change and relocation of activity spheres. The patterns in SW Brabant and Hainault are likely to be related since these regions are closely connected spatially. If the residential shift from the Ourthe Basin also was directed into the loess region, as is claimed by Henrard (2003), is difficult to determine. Data on the Mesolithic occupation of the 
Hesbaye region located near the Ourthe Basin, are unfortunately lacking. A similar shift in site or activity location choice is also visible, albeit on a smaller spatial scale, within the Hageland region (see above). In the Meuse valley regions, with a continuous drop from Pre-boreal to Late Boreal, no particular middle Boreal shift can be noted.

A shift in occupation patterns from the Final Palaeolithic and Early Mesolithic to the Middle and Late Mesolithic has been observed elsewhere as well. In Sandy Flanders and the Belgian Campine area, this shift is associated with environmental changes: as Late Glacial lakes disappeared, the occupations shifted towards the river valleys and the exploited hinterland was reduced due to an increasing vegetation cover and the associated reduction of undergrowth and change in fauna (Crombé and Verbruggen, 2002; Vanacker et al., 2001). The increasing vegetation cover may also be responsible for the shift in SW Brabant, Hageland and Ourthe Basin or for the decreasing trend in the other regions. Interpreted this way, these trends fit well with the shift in settlement pattern noted for most of Central and Western Europe's Mesolithic and related to the increasing vegetation cover (e.g. Gronenborn, 1999, p. 137). The rise of activity in Hainault is remarkable; especially since this region will have experienced a similar vegetation change as in SW Brabant.

In the Ourthe Basin, SW Brabant and Hageland, the Boreal shift is maintained in the later Mesolithic. In Hainault, on the other hand, it is reversed and again much lower numbers of microliths are found. None of the other regions compensate for this drop with a clear rise in the Atlantic period, unless the unknown factor with which non-trapeze microliths should be divided for comparison with trapezes (see above) is taken into account. Every likely factor, i.e. larger than 1, implies a notable activity rise in SW Brabant and in the Meuse Valley 'core regions'. Environmental changes can be invoked as an explanation for the shift in Hainault. The region is deserted due to a continuing increase of the vegetation cover. The microlith number increase in the Late Boreal period and the Late Boreal to Atlantic moderate rise in SW Brabant, however, do not fit with this explanation. If the patterns are related, it seems that there was at least a partial 'retreat' of activity from Hainault into SW Brabant.

\section{A farmer-forager connection?}

\section{The arrival of the $L B K$}

Around $5300 \mathrm{cal} \mathrm{BC}$, in the second part of the Atlantic period, the people of the Linearbandkeramik culture settled in the Scheldt and Meuse Basins loess region (Jadin and Cahen, 2003a,b). A series of settlement clusters covered the Aldenhovener Platte, the Graetheide and Hesbaye regions, with a small western outlier along the Kleine Gete River (Fig. 5). Approximately $100 \mathrm{~km}$ further west, a single, isolated settlement cluster was located in the region of the upper Dendre River, in the present-day province Hainault (Jadin, 2003; fig. 5). It is thought to have been a pioneer extension of the later LBK, as it only consists of few settlements and is located at a large distance to the nearest cluster in Hesbaye. Apparently these pioneer communities did not colonize their wider environment, as is the case farther east. Recent data for the Dutch southern Limburg area point in contrast to a growing flexibility in site location choices of the LBK in the later phases, resulting in the colonisation of the wider environment around the traditionally occupied loess plateaus (Amkreutz, in press; Amkreutz et al., in press).

It has long been debated whether the isolated position of the Hainault cluster corresponds to an actual settlement pattern or that intermediate LBK settlement clusters have been missed and are still awaiting discovery (see also Jadin, 2003, p. 75). The physiography of the intermediate area with respect to the main LBK location-determining factors, i.e. a combination of soil, topography and water, does not significantly differ from that of both LBK areas. On the other hand, recent surveys and archaeological investigation of major transects through the middle Belgian loess region for the construction of high-speed railroads and gas pipelines did not yield new LBK settlement traces beyond the known clusters (see also Jadin, 2003, p. 75).

The large spatial gap can thus not be explained by research activity or by the traditional view on the preferred settlement location. It may have been socially induced, connected to the region's social geography. Microlith distribution patterns in the region can be used as a proxy for the hunter-gatherer occupation. Fig. 5 presents a map combining all Mesolithic microliths presented in the first part of this paper and the LBK settlement clusters. The spatial separation of both is remarkable: the LBK cluster regions are strikingly empty in microliths. As those regions have been intensely surveyed in the past, Mesolithic microliths would surely have been recognised. Only for the Hesbaye region one can rightly stress that no data are included in this paper, but the absence of readily available data can also be regarded as an indication of the limited number of finds. The scrutiny of all available public and private archaeological collections of the Graetheide plateau by M. Wansleeben and L. Verhart ensures the absence of Mesolithic artefacts there. The same is true for the area around both Kleine Gete and Hezerwater LBK clusters, for which not a single Mesolithic site or artefact is known. Apart from the residual point with invasive retouch from a pit in Blicquy-Couture du Couvent (Constantin et al., 1991), only two Middle Mesolithic sites have been identified in the area of the Hainault LBK cluster (Pleuger et al., 2005; Van Assche and Demarez, 2005).

The microlith deficiency in precisely those parts of the loess belt where LBK settled from 5300 cal BC onwards is a primary pattern. Hunter-gatherers apparently avoided these regions in their exploitation of the loess zone. This holds for wide stretches, including the German Rhineland, while the Scheldt Basin microliths are a striking exception. It is unlikely that the unattractiveness of particular zones for foragers is only due to the particular physiography and related vegetation cover; the scarcity of hunter-gatherer remains is a constant throughout the entire Early Holocene, notwithstanding the major environmental changes taking place during that period and the similar soil conditions in and beyond those particular zones. The avoidance of these zones is independent of the LBK arrival as well, since sites or microliths from the entire Mesolithic period are lacking.

Whatever the reason for this spatial patterning of hunter-gatherer activity, it seems that it limited the site location choice of the LBK. People of the LBK settled in exactly those areas only marginally exploited by hunter-gatherers and not in the intermediate regions with similar physiography but more intense hunter-gatherer exploitation. This fits the idea of an initially demic diffusion of the LBK at least in the western Rhineland, Dutch southern Limburg and Belgian Hesbaye. Other arguments in its favour are the absence of microliths integrated in early LBK settlements, ${ }^{4}$ the absence of transitional complexes and the large cultural contrast between LBK and the late Mesolithic as currently understood (Louwe Kooijmans, in press). It should be stressed, however, that this principally demic movement does not a priori exclude the possibility of forager-farmer interactions including the integration of foragers in the LBK society.

\section{Forager reaction to incoming farmers}

The individual microlith distributions allow identifying several distinctive patterns. First, hunter-gatherers exploited the loess re-

\footnotetext{
4 A few examples exist of points with invasive retouch found in LBK context and even in Michelsberg context (cf. Jeunesse, 2000). However, as no other arguments exist to accept the continued use of such point types during the Late Mesolithic, these should rather be regarded as residual (cf. Crombé et al., 2005; Van Assche, 2005).
} 


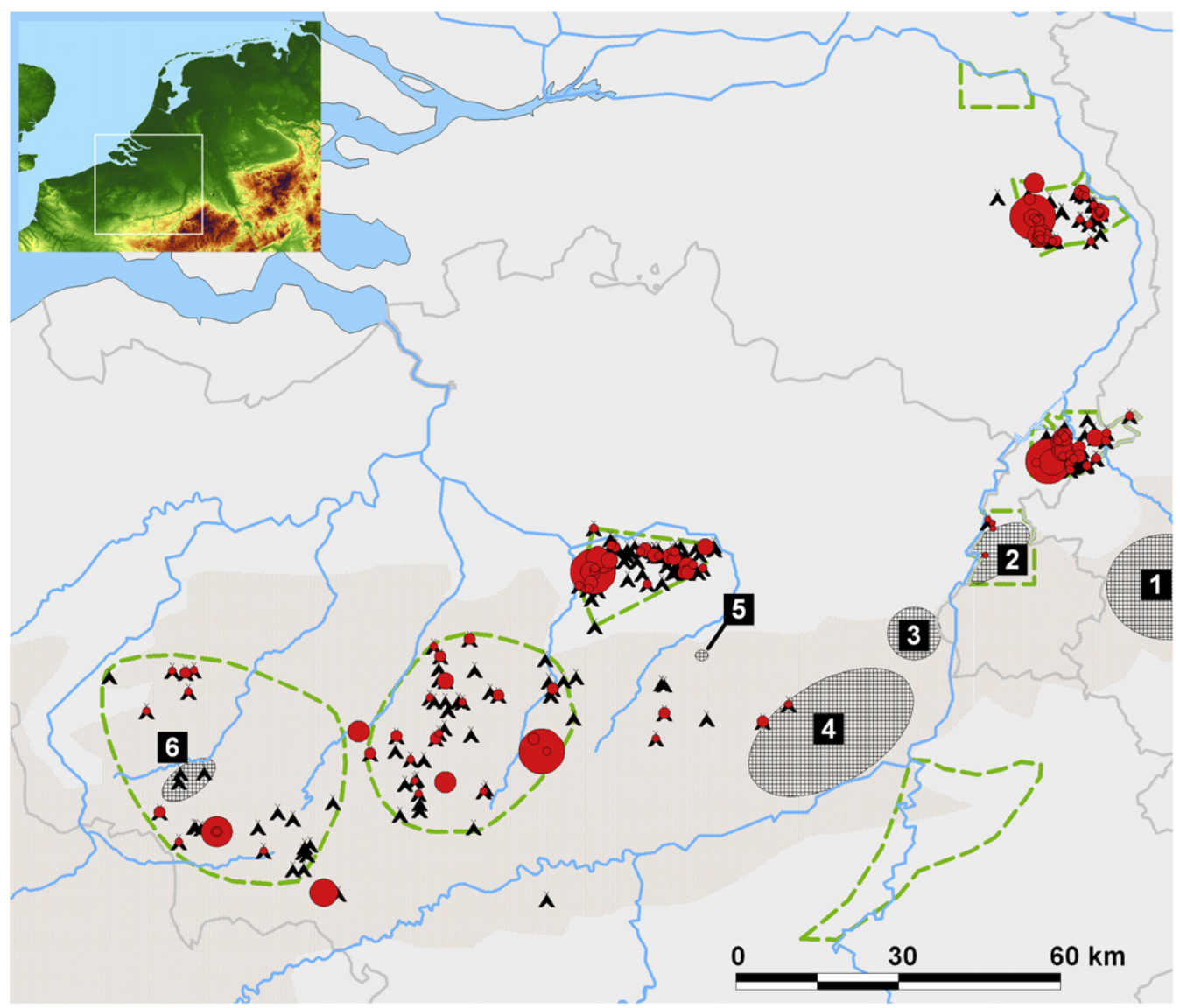

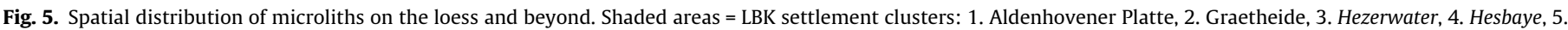

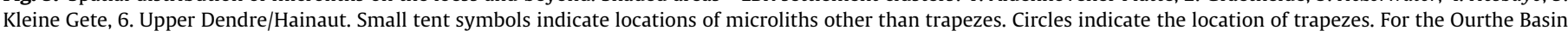
and Grave region, no microliths are plotted due to a lack of spatial information.

gion randomly, with the exception of some areas including those later to be occupied by the LBK. Second, a shift in exploitation or occupation locations occurred around the middle of the Boreal period. Third, those regions close to later LBK settlement clusters have experienced a different occupation or exploitation history.

In Gregg's 'mutualistic interaction' model for Southern Germany, low density, residentially mobile hunter-gatherers were attracted to the rich environments of the first farmers' settlements (Gregg, 1988, p. 234). This paper's loess belt exploitation changes do not show such attraction and the presumed related rise in microliths. From the Graetheide area more trapezes were recovered than older type microliths, but the small absolute number does not allow interpreting them as proof for an attraction to the LBK settlements. The main pattern is that of a marked drop in Atlantic points in Hainault and a moderate increase in SW Brabant and the Meuse Valley regions. If anything, this shows that the possible environmental influence driving the hunter-gatherers away from the loess region was complemented with a factor driving the activity back into SW Brabant. Either the LBK communities are responsible for the retreat of the remaining hunter-gatherers exploiting Hainault or hunter-gatherer activity lasted longer farther away from the LBK settlements, perhaps contemporaneous with them.

The spatial separation between LBK and the local Mesolithic is one of Keeley's arguments in favour of an actively hostile relationship between LBK and local hunter-gatherers (Golitko and Keeley, 2007; Keeley, 1992). Other arguments are the scarcity of reliable contact finds and signs of acculturation, the absence of wild food sources in LBK context and domestic food sources in Mesolithic context and the presence of LBK enclosures at the fringe of LBK settlement territory in Hesbaye (Golitko and Keeley, 2007; Keeley, 1992). These arguments can, however, be refuted. The movement of goods is difficult to identify in the archaeological record of the area due to taphonomical reasons (e.g. Zvelebil, 1998). Nevertheless, many of the LBK adzes found well beyond the LBK settlement zones can be interpreted as prestigious exchange goods (e.g. Verhart, 2000). The local LBK use of Phtanite/Lydite but also of Wommersom quartzite, two raw materials frequently used during the Mesolithic, is a possible but contentious indication for a transfer in the opposite direction (Vanmontfort, 2007). The same taphonomic factors can be responsible for the absence of evidence for 'Mesolithic' use of domesticates and the Neolithic exploitation of wild food resources (see e.g. Modderman, 1988 for the exploitation of wild fauna by the LBK). With respect to the LBK enclosures, the absence of evidence of actual violence makes it difficult to associate them with hostile local hunter-gatherers (see also Jadin and Cahen, 2003a,b). Such a relationship would even be expected to lead to a concentration of Mesolithic arrow implements near LBK sites, which is obviously not the case (see above). A hostile relationship cannot be deduced from the spatial exclusion of LBK settlements and hunter-gatherer activity either. The choice of the LBK people to settle in regions at most marginally exploited by local peoples can even be interpreted as a conflict-avoiding attitude.

The observed patterns best fit with an open static or stationary agricultural frontier zone (a.o. Dennell, 1985; Zvelebil, 1998; Zvelebil, 2001; Zvelebil, 2004). This encompasses the bi-directional movement of goods, among which the LBK adzes, and the longevity of a static frontier. From the arrival of the LBK onwards, the agricul- 
tural frontier zone apparently developed in a stable or only slowly changing situation with a long availability phase (cf. Zvelebil, 2004).

To conclude, the following model can be put forward. During the 6th Millennium cal BC, major parts of the loess region are exploited by a low density of hunter-gatherers. The LBK communities settle at arrival in locations fitting their preferred physical characteristics, but void of hunter-gatherer activity. Evidently, multiple processes and contact situations may have occurred simultaneously, but in general the arrival of the LBK did not attract hunter-gatherer hunting activity. Their presence rather restrained native activity to regions located farther away from the newly constructed settlements or triggered fundamental changes in the socio-economic organisation and activity of local hunter-gatherers. Evidence for the subsequent step in the transition dates to approximately one millennium later (Crombé and Vanmontfort, 2007; Vanmontfort, 2007).

\section{Conclusion}

This paper shows that, despite the difficulties associated with taphonomy and site preservation or identification, some patterns of hunter-gatherer activity in the loess region can be assessed on the basis of individual microliths rather than on closed and welldated sites or assemblages. Some of these patterns reveal a mutual influence of immigrant Neolithic farmers and local hunter-gatherers. Apparently, LBK settlement location choice was determined by the hunter-gatherer activity radii as well as environmental factors. LBK communities avoided those regions more intensely exploited by hunter-gatherers. Conversely, hunter-gatherer activity retreated to the regions farther away from the Neolithic villages. The visibility of this influence is an indication in favour of the contemporaneity of LBK and local hunter-gatherers and the probability of interaction. Future research should show whether this hypothesis of spatial exclusion between forager and farmer exploitation and settlement territories actually corresponds to an archaeological reality. A more detailed interpretation of patterns can be obtained by applying the method to a wider region, including larger parts of the loess belt of the Scheldt, Meuse and Rhine Basins as well as the neighbouring regions. More detailed spatial analysis should allow identifying intraregional shifts in activity, as is already demonstrated for the Hageland region. The application of the method to data from the Central European loess region should reveal the extent of the identified pattern. The detailed study of LBK points/trapezes (Robinson, in preparation) should allow an improvement of the chronological resolution of the Late and Final Mesolithic phase and consequently of the appreciation of foragerfarmer interaction. In the end all this should lead to a better understanding of the Mesolithic-Neolithic transition.

\section{Acknowledgments}

The research for this paper is part of the "From Hardinxveld to Noordhoorn: From Forager to Farmer"-project of Leiden University, financed by NWO (Netherlands Organisation for Scientific Research) in the framework of the "Malta's Harvest" programme. L. Verhart and M. Wansleeben kindly allowed the use of their Meuse Valley Project-data. We are indebted to L. Amkreutz, M. De Bie, L.P. Louwe Kooijmans, E. Robinson, L. Verhart, M. Van Gils, P.M. Vermeersch and two anonymous reviewers for their helpful comments and related discussions on earlier drafts of this paper and M. Epperson for proof reading the English text.

\section{References}

Amkreutz, L.W.S.W., in press. All quiet on the Northwestern front? An overview and preliminary analysis of the past decade of LBK-research in the Netherlands. In:
Gronenborn, D. (Ed.), Die Neolithisierung Mitteleuropas. Internationale Tagung, Mainz 24.-26. Juni 2005, Mainz.

Amkreutz, L.W.S.W., Vanmontfort, B., Verhart, L.B.M., in press. Diverging trajectories? Forager-farmer interaction in two adjacent regions. In: Hofmann, D., Bickle, P. (Eds.), New Advances in Central European Neolithic Research.

Binford, L.R., 1982. The archaeology of place. Journal of Anthropological Archaeology 1, 5-31.

Bogucki, P.I., 1988. Forest farmers and stockherders. Early Agriculture and its Consequences in Northcentral Europe. Cambridge.

Bogucki, P.I., Grygiel, R., 1993. The first farmers of central Europe: a survey article. Journal of Field Archaeology 20, 399-426.

Bosquet, D., Jadin, I., 1996. Rebecq (Bt). Un site mésolithique ancien au lieu-dit “Le Spinoi. In: Rémy, H., Soumoy, M. (Eds.), Sur la voie de l'histoire: Archéologie et TGV. Namur, pp. 155-158.

Constantin, C., Farruggia, J.-P., Demarez, L. 1991. Le site rubané de Blicquy-la Couture du Couvent (Hainaut). Fouilles 1983-85-88. Les Chercheurs de la Wallonie 31, 51-78.

Crombé, P., 1998. The Mesolithic in Northwestern Belgium. Recent excavations and surveys. Oxford.

Crombé, P., 2002. Quelques réflexions sur la signification de la variabilité des industries lithiques mésolithiques de Belgique. In: Otte, M., Kozlowski, J.K. (Eds.), Préhistoire de la grande plaine du Nord de l'Europe: Les échanges entre l'Est et l'Ouest dans es sociétés préhistoriques. Actes du Colloque Chaire Franqui interuniversitaire (Université de Liège, 26 juin 2001). Université de Liège, Liège, pp. 99-114.

Crombé, P., Cauwe, N., 2001. The Mesolithic. Anthropologica et Praehistorica 112, 49-62.

Crombé, P., Perdaen, Y., Sergant, J. 2005. La néolithisation de la Belgique: quelques réflexions. In: Marchand, G., Tresset, A. (Eds.), Unité et diversité des processus de néolithisation sur la façade atlantique de l'Europe (6e-4e millénaires avant J.-C.), Table ronde de Nantes, 26-27 Avril 2002, Paris, pp. 47-66.

Crombé, P. Vanmontfort, B., 2007. The neolithisation of the Scheldt basin in western Belgium. In: Whittle, A., Cummings, V. (Eds.), Going Over: The MesolithicNeolithic Transition in North-West Europe. Oxford University Press, Oxford, pp. 263-285.

Crombé, P., Verbruggen, C. 2002. The late glacial and early post glacial occupation of northern Belgium: the evidence from Sandy Flanders. In: Eriksen, B., Bratlund, B. (Eds.), Recent Studies in the Final Palaeolithic of the European plain, Proceedings of a U.I.S.P.P. Symposium, Stockholm 14-17 October 1999, Arhus, pp. $165-180$.

De Bie, M., Van Gils, M., in press. Mesolithic settlement and land use in the Campine region (Belgium). In: Woodman, P., McCartan, S. (Eds.), Meso 2005. Proceedings of the 7th International Conference on the Mesolithic in Europe (Belfast, Northern Ireland, August 29-September 2). Oxbow, Oxford.

Dennell, R.W., 1985. The hunter-gatherer/agricultural frontier in prehistoric temperate Europe. In: Green, S.W., Perlman, S.M. (Eds.), The Archaeology of Frontiers and Boundaries. Academic Press, Orlando, pp. 113-136.

Donahue, R.E., Lovis, W.A., 2006. Regional settlement systems in Mesolithic northern England: Scalar issues in mobility and territoriality. Journal of Anthroplogical Archaeology 25, 248-258.

Ducrocq, T., 2001. Le Mésolithique du bassin de la Somme: Insertion dans un cadre morpho-stratigraphique, environnemental et chronoculturel. Université des Sciences et Technologies de Lille, Villeneuve d'Ascq.

Ebert, J.I., 1992. Distributional Archaeology. University of New Mexico Press, Albuquerque.

Fourny, M., Van Assche, M., 1987. Nouveaux sites d'habitat du Neolithique moyen entre Senne et Dyle. Notae Praehistoricae 7, 8-10.

Fourny, M., Van Assche, M., 1993. Le site néolithique Michelsberg de Braine-l'Alleud "Paudure" (Brabant): Sondages et Prospections. Amphora 69.

Garnett, A., 1945. The loess regions of central Europe in prehistoric times. The Geographical Journal 106, 132-143.

Gob, A., 1981. Le Mésolithique dans le bassin de l'Ourthe. Liège.

Gob, A., 1985. Extension géographique et chronologique de la culture RheinMeuse-Schelde (RMS). Helinium 25, 23-36.

Gob, A., 1990. Du mésolithique au néolithique en Europe nord-occidentale: un point de vue du mésolithicien. In: Cahen, D., Otte, M. (Eds.), Rubané et Cardial. Actes du Colloque de Liège. Université de Liège, Liège, pp. 155-159.

Golitko, M., Keeley, L., 2007. Beating ploughshares back into swords: warfare in the Linearbandkeramik. Antiquity 81, 332-342.

Goossens, D., 1983. Inleiding tot de geologie en geomorfologie van België. Enschede.

Gregg, S.A., 1988. Forager and Farmers: Population Interaction and Agricultural Expansion in Prehistoric Europe. The University of Chicago Press, Chicago.

Gronenborn, D., 1999. A variation on a basic theme: the transition to farming in southern central Europe. Journal of World Prehistory 13, 123-210.

Heinen, M., 2006. The Rhine-Meuse-Schelde Culture in Western Europe. Distribution, Chronology and Development. In: Kind, C.-J. (Ed.), After the Ice Age: Settlements, Subsistence and Social Development in the Mesolithic of Central Europe. Konrad Theiss Verlag, Stuttgart, pp. 75-86.

Henrard, D., 2003. Le Mésolithique du bassin de l'Ourthe (Belgique): implantation dans le paysage et néolithisation. L'Anthropologie 107, 615-644.

Jadin, I., 2003. Trois petits tours et puis s'en vont. La fin de la présence danubienne en Moyenne Belgique (avec la participation de D. Cahen, I. Deramaix, A Hauzeur, J. Heim, A. Livingstone Smith, J. Verniers). Université de Liège, Liège.

Jadin, I., Cahen, D., 2003. Datations radiocarbones et Rubané: Pour un mariage de raison, I. Jadin 2003, pp. 523-581. 
Jadin, I., Cahen, D., 2003. Sites en pagaille sur le haut Geer: Darion, Oleye, Waremme-Longchamp, Hollogne-Douze Bonnier, I. Jadin 2003, pp. 191-315.

Jeunesse, C., 2000. Les composantes autochtone et danubienne en Europe centrale et occidentale entre 5500 et 4000 av. J.-C.: contacts, transferts, acculturations. In: Richard, A., Cupillard, C., Richard, H., Thévenin, A. (Eds.), Les derniers chasseurs-ceuilleurs d'Europe occidentale. Actes du colloque international de Besançon (octobre 1998), Besançon, pp. 361-378.

Jochim, M.A., 1990. The Late Mesolithic in Southwest Germany: Culture Change or Population Decline? In: Vermeersch, P.M., Van Peer, P. (Eds.), Contributions to the Mesolithic in Europe, pp. 183-191.

Keeley, L.H., 1992. The introduction of agriculture to the western north European plain. In: Gebauer, A.B., Price, T.D. (Eds.), Transitions to Agriculture in Prehistory. Prehistory Press, Madison (Wisconsin), pp. 81-95.

Kelly, R.L., 1995. The Foraging Spectrum. Smithsonian, Washington, DC.

Kind, C.-J., 1997. Die letzten Wildbeuter. Henauhof Nord II und das Endmesolithikum in Baden-Württemberg. mit Beiträgen von Helga LieseKleiber, Alfred Pawlik und Richard Vogt. Konrad Theiss Verlag, Stuttgart.

Kind, C.-J., 2003. Das Mesolithikum in der Talaue des Neckars. Die Fundstellen von Rottenburg Siebenlinden 1 und 3. Mit beiträgen von Ann M. Miller und Joachim Hahn. Konrad Theiss Verlag, Stuttgart.

Koch, I., 1998. Das Mesolithikum im Trierer land. Archäologische Informationen 21, 387-391.

Lanting, J.N., van der Plicht, J., 1997/1998. De C14 chronologie van de Nederlandse Pre-en Protohistorie, II: Mesolithicum. Palaeohistoria 39/40, 1-162.

Leopold, L.B., Vita-Finzi, C., 2005. Archaeological trash: geomorphology and early human occupation in Wyoming. Catena 62, 1-13.

Louwe Kooijmans, L.P., 2007. The gradual transition to farming in the Lower Rhine Basin. In: Whittle, A., Cummings, V. (Eds.), Going Over: the Mesolithic-Neolithic Transition in North-West Europe. Oxford University Press, Oxford, pp. 287-309.

Louwe Kooijmans, L.P., in press. The gradual transition to farming in the Lower Rhine Basin. In: Whittle, A., Cummings, V. (Eds.), Going Over: The MesolithicNeolithic Transition in North-West Europe. Cardiff.

Lovis, W.A., Donahue, R.E., Holman, M., 2005. Long distance logistic mobility as an organizing principle among northern hunter-gatherers: a Great Lakes Middle Holocene settlement system. American Antiquity 70, 669-693.

Mees, N., Plumier, J., Munaut, A.V., Defgnée, A., Van Neer, W., 1994. Premier état des recherches sur le néolithique et le mésolithique au Grognon à Namur. Notae Praehistoricae 14, 109-112.

Modderman, P.J.R., 1988. The Linear Pottery Culture: diversity in uniformity. Berichten van de Rijksdienst voor het Oudheidkundig Bodemonderzoek 38, 63140.

Parent, J.-P., Van Der Plaetsen, P., Vanmoerkerke, J., 1987. Prehistorische jagers en veetelers aan de Donk te Oudenaarde. Vobov-info, 24-25.

Pleuger, E., Paridaens, N., Gillet, E., Van Assche, M., 2005. Une fosse mésolithique découverte à Leuze-en-Hainaut/Blicquy Ville d'Anderlecht" (Hainaut). Amphora 83, 19-24.

Price, T.D., 2000. Lessons in the transition to agriculture. In: Price, T.D. (Ed.), Europe's First Farmers. Cambridge University Press, Cambridge, pp. 301-318.

Robinson, E.N., in preparation. The evolution of trapeze industries and the role of armatures in Neolithisation models for northwest Europe: a systematic approach. In: Crombé, Ph., Van Strydonck, M. (Eds.), Chronology and evolution in the Mesolithic of $\mathrm{N}(\mathrm{W})$ Europe.

Rozoy, J.G., 1978. Les derniers chasseurs. L'Epipaleolithique en France et en Belgique. Essai de synthèse. Charleville.

Street, M., 1995. Bedburg-Königshoven. In: Bosinski, G., Street, M., Baales, M. (Eds.), The Palaeolithic and Mesolithic of the Rhineland. In: Schirmer, W. (Ed.), Quaternary Field Trips in Central Europe. Bonn, pp. 962-966.

Street, M., Baales, M., Cziesla, E., Hartz, S., Heinen, M., Jöris, O., Koch, I., Pasda, C., Terberger, T., Vollbrecht, J., 2001. Final paleolithic and Mesolithic research in reunified Germany. Journal of World Prehistory 15, 365-453.

Thévenin, A., 1992. Mésolithique récent, Mésolithique final, Néolithique ancien dans le Nord-Est de la France et régions voisines. Le problème entrevu par les armatures. In: Le Roux, C.-T. (Ed.), Paysans et Batisseurs. L'émergence du Néolithique atlantique et les origines du Mégalithisme. Actes du 17ème colloque interrégional sur le Néolithique, Vannes, 28-31 octobre 1990, pp. 101-110.

Tringham, R., 2000. Southeastern Europe in the transition to agriculture in Europe: bridge, buffer or mosaic. In: Price, T.D. (Ed.), Europe's First Farmers. Cambridge University Press, Cambridge, pp. 19-56.

Van Assche, M., 2005. Aperçu sur le mésolithique des régions d'Ath et de Mons (Hainaut). Amphora 83, 42-82.

Van Assche, M., Demarez, L., 2005. Le site mésolithique moyen d'Ath/Ormeignies "Autreppe" (Hainaut). Amphora 83, 3-18.

van de Konijnenburg, R., 1980. Het Mesolithicum in Henegouwen en Brabant ten zuiden van de lijn Roosdaal-Brussel-Orp-Jauche, (Unpublished Master's thesis), Katholieke Universiteit Leuven, Leuven.

van der Sloot, P., Damblon, F., Debenham, N., Fechner, K., Gob, A., Haesaerts, P., Hauzeur, A., Jadin, I., Léotard, J.-M., Remacle, M., Vanmontfort, B., 2003. Le Mésolithique et le Néolithique du site Saint-Lambert à Liège dans leur contexte chronologique, géologique et environnemental. Synthèse des données et acquis récents. Notae Praehistoricae 23, 79-104.

Van Gijn, A., Louwe Kooijmans, L., 2005. The first farmers: synthesis. In: Louwe Kooijmans, L.P., van den Broeke, P.W., Fokkens, H., van Gijn, A.L. (Eds.), The Prehistory of the Netherlands. Amsterdam University Press, berlin.

Vanacker, V., Govers, G., Van Peer, P., Verbeek, C., Desmet, J., Reyniers, J., 2001. Using Monte Carlo simulation for the environmental analysis of small archaeologic datasets, with the Mesolithic in northeast Belgium as a case study. Journal of Archaeological Science 28, 661-669.

Vanmontfort, B., 2007. Bridging the gap. The Mesolithic-Neolithic transition in a frontier zone. Documenta Praehistorica XXXIV, 105-118.

Verhart, L.B.M., 2000. Times fade away: The neolithization of the southern Netherlands in an anthropological and geographical perspective. Leiden.

Verhart, L.B.M., 2003. Mesolithic Economic and Social Changes in the Southern Netherlands. In: Larsson, L., Kindgren, H., Knutsson, K., Loeffler, D., Akerlund, A. (Eds.), Mesolithic on the Move, Papers presented at the Sixth International Conference on the Mesolithic in Europe, Stockholm 2000. Oxford, pp. 442-450.

Vermeersch, P.M., 1976. Steentijdmateriaal uit het Noordelijk Hageland. Nationaal Centrum voor Oudheidkundige Navorsingen in België, Brussel.

Vermeersch, P.M., 1984. Du Paleolithique final au Mesolithique dans le nord de la Belgique. In: Cahen, D., Haesaerts, P. (Eds.), Peuples chasseurs de la Belgique préhistorique dans leur cadre naturel, Bruxelles, pp. 181-193.

Vermeersch, P.M., 1990. La transition du Mésolithique au Néolithique en Basse et Moyenne Belgique. In: Cahen, D., Otte, M. (Eds.), Rubané et Cardial. Actes du Colloque de Liège. Université de Liège, Liège, pp. 96-103.

Wansleeben, M., Verhart, L., 1998. Graphical analysis of regional archaeological data. The use of site typology to explore the Dutch neolithization process. Internet Archaeology 4.

Zvelebil, M., 1996. The agricultural frontier and the transition to farming in the circum-Baltic region. In: Harris, D.R. (Ed.), The Origins and Spread of Agriculture and Pastoralism in Eurasia. London, pp. 323-345.

Zvelebil, M., 1998. Agricultural frontiers, Neolithic origins, and the transition to farming in the Baltic basin. In: Zvelebil, M., Dennell, R., Domanska, L. (Eds.), Harvesting the Sea, Farming the Forest. Sheffield, pp. 9-27.

Zvelebil, M., 2000. Les derniers chasseurs-collecteurs d'Europe tempérée. In: Richard, A., Cupillard, C., Richard, H., Thévenin, A. (Eds.), Les derniers chasseurs-ceuilleurs d'Europe occidentale. Actes du colloque international de Besançon, octobre 1998, Besançon, pp. 379-406.

Zvelebil, M., 2001. The agricultural transition and the origins of Neolithic society in Europe. Documenta Praehistorica XXVIII, 1-26.

Zvelebil, M., 2004. The many origins of the LBK. In: Lukes, A., Zvelebil, M. (Eds.), LBK dialogues, Studies in the formation of the Linear Pottery Culture. Archaeopress, Oxford, pp. 183-205.

Zvelebil, M., Lillie, M., 2000. Transition to agriculture in eastern Europe. In: Price, T.D. (Ed.), Europe's First Farmers. Cambridge University Press, Cambridge, pp. 57-92.

Zvelebil, M., Rowley-Conwy, P., 1986. Foragers and farmers in Atlantic Europe. In: Zvelebil, M. (Ed.), Hunters in Transition: Mesolithic Societies of Temperate Europe and their Transition to Farming. Cambridge, pp. 67-93. 